\title{
Mechanical and water vapor permeability properties of biodegradables films based on methylcellulose, glucomannan, pectin and gelatin
}

\author{
Propriedades mecânicas e de permeabilidade ao vapor de água de filmes biodegradáveis à base de \\ metilcelulose, glucomanana, pectina e gelatina
}

\author{
Hulda Noemi Mamani CHAMBI ${ }^{1 *}$, Carlos Raimundo Ferreira GROSSO ${ }^{1}$
}

\begin{abstract}
Mimic biological structures such as the cell wall of plant tissues may be an alternative to obtain biodegradable films with improved mechanical and water vapor barrier properties. This study aims to evaluate the mechanical properties and water vapor permeability (WVP) of films produced by using the solvent-casting technique from blended methylcellulose, glucomannan, pectin and gelatin. First, films from polysaccharides at $\mathrm{pH} 4$ were produced. The film with the best mechanical performance (tensile strength $=72.63 \mathrm{MPa}$; elongation $=9.85 \%$ ) was obtained from methylcellulose-glucomannan-pectin at ratio 1:4:1, respectively. Then, gelatin was added to this polysaccharide blend and the $\mathrm{pH}$ was adjusted to 4, 5 and 6. Results showed significant improvement in WVP when films were made at pH 5 and at polysaccharides/gelatin ratio of $90 / 10$ and 10/90, reaching 0.094 and 0.118 g.mm $/ \mathrm{h} \cdot \mathrm{m}^{2} . \mathrm{kPa}$ as values, respectively. Films with the best mechanical properties were obtained from the blend of polysaccharides, whereas WVP was improved from the blend of polysaccharides and gelatin at pH 5.

Keywords: polysaccharides; proteins; films; biodegradable materials.
\end{abstract}

\section{Resumo}

Mimetizar estruturas biológicas como a parede celular dos tecidos vegetais pode ser uma alternativa para obter filmes biodegradáveis com propriedades mecânicas e de barreira ao vapor de água melhoradas. O objetivo do presente trabalho foi avaliar as propriedades mecânicas e de permeabilidade ao vapor de água (PVA) de filmes produzidos pelo método de evaporação do solvente (casting) a partir de misturas de metilcelulose, glucomanana, pectina e gelatina. Inicialmente, foram produzidos filmes a partir dos polissacarídeos em $\mathrm{pH} 4$. O filme com melhor desempenho mecânico (tensão na ruptura = 72,64 MPa; elongação =9,85\%) foi obtido a partir de metilcelulose-glucomanana-pectina na proporção 1:4:1, respectivamente. Posteriormente, adicionou-se gelatina a esta mistura de polissacarídeos, e o pH foi ajustado para 4, 5 e 6. Os resultados mostraram melhoras significativas na PVA quando os filmes foram produzidos em $\mathrm{pH} 5 \mathrm{e}$ com as proporções polissacarídeos/gelatina de $90 / 10$ e 10/90, atingindo-se valores de 0,094 e 0,118 g.mm/h.m².kPa, respectivamente. Filmes com melhores propriedades mecânicas foram obtidos a partir da mistura dos polissacarídeos, enquanto que a PVA foi melhorada a partir da mistura dos polissacarídeos com a gelatina em pH 5.

Palavras-chave: polissacarídeos; proteínas; filmes; materiais biodegradáveis.

\section{Introduction}

Interest in edible films is connected with the development of easily degradable packaging, non-aggressive to the environment (CHEN, 1995; KOELSCH, 1994). Natural polymers such as proteins and polysaccharides, offer great opportunities, since their biodegradability and environmental compatibility are assured (KROCHTA; DE MULDER-JOHNSON, 1997). However, films produced with these materials have low water vapor barrier property and low mechanical resistance in comparison with films produced from synthetic polymers.

Several studies have been carried out to improve film performance such as the cross-linking of the polymeric chains (CARVALHO; GROSSO, 2004; HERNÁNDEZ-MUÑOZ; VILLALOBOS; CHIRALT, 2004; CHAMBI; GROSSO, 2006), the addition of hydrophobic compounds (TANADA-PALMU; GROSSO, 2002; BERTAN et al., 2005) and blended polysaccharides and/or proteins (XIAO et al., 2001a,b; CIEŚLA; SALMIERI; LACROIX, 2006; WANG et al., 2007).

Another alternative to obtain films with good performance would be through mimic biological structures such as the cell wall composed of a three-dimensional network of cellulose, pectin, hemicelluloses (xylan, mannans, xyloglucans) and structural proteins (CHANLIAUD et al., 2002; KERSTIENS, 1996). This network should be able to bear high-strain strength allowing reversible deformation, in reply to the osmotic pressure caused by the cell turgescence (CHANLIAUD et al., 2002).

Cellulose, the most abundant organic polymer in the world, is a linear homopolymer constituted by glucose molecules linked by highly polar and hydrophilic glycosidic bonds $\beta(1-4)$; however, it is insoluble in water (JUNQUEIRA, 1997). In order to provide solubility, cellulose is esterified

Received $7 / 12 / 2009$

Accepted 24/3/2010 (004540)

${ }^{1}$ Food \& Nutrition Department, Faculty of Food Engineering, State University of Campinas - UNICAMP, Rua Monteiro Lobato, 70, CEP 13083-862, Campinas, SP, Brazil, e-mail:huldanoemi@yahoo.com.br

${ }^{*}$ Corresponding author 
with aqueous caustic soda, and then with methyl chloride, propylene oxide or sodium monochloroacetate to yield methylcellulose (MC), hydroxypropyl methylcellulose (HPMC), hydroxypropylcellulose (HPC) and sodium carboxymethylcellulose (CMC) (ZECHER; GERRISH, 1997). $\mathrm{MC}$ is the least hydrophilic cellulose ester, which shows thermal gelation and makes excellent films (DONHOWE; FENNEMA, 1993; DEBEAUFORT; VOILLEY, 1997; TURHAN; SAHBAZ, 2004).

From the hemicelluloses, glucomannan has been studied in films production (KOHYAMA et al., 1992; YOO; LEE; LIM, 1997; CHENG et al., 2002). Glucomannan is a non-ionic polysaccharide composed by glucose and mannose units linked by $\beta(1-4)$ bonds with ramifications every $10-11$ residues in the primary chain (MAEDA et al., 1999), and it is mainly obtained from Amorphophallus konjac C. Koch.

Pectin is a polysaccharide rich in D-galacturonic acid that is mainly obtained from citric peels or apple skin (MAY, 1997) and it may have high or low level of esterification degree; it is also used for films production (MAFTOONAZAD; RAMASWAMY; MARCOTTE, 2007; LIU et al., 2007).

The structural proteins in the cell wall are classified as to their predominant amino acid composition: hydroxyproline-rich glycoproteins, proline-rich proteins and glycine-rich proteins (CARPITA; MCCANN, 2000; TAIZ; ZEIGER, 2002). Gelatin is a protein of animal origin, obtained from collagen and it has functional properties that are suitable for film production (DJAGNY; WANG; XU, 2001; CAO; YANG; FU, 2009). In addition, it has a high content of hydroxyproline, proline and glycine amino acids, present in high concentrations in the cell wall structural proteins (GENNADIOS et al., 1994; CARPITA; MCCANN, 2000; TAIZ; ZEIGER, 2002).

Most studies focus on the use of two biopolymers in film production as the binary blends of glucomannan/sodium carboxymethylcellulose, cassava starch/arabinoxylan, agar/ arabinoxylan, and agar/cassava starch (XIAO et al., 2001a; PHAN THE et al., 2009). Films from three polysaccharides were obtained by Tong, Xiao and Lim (2008), who blended pullulan with alginate and carboxymethylcellulose. Wang et al. (2007) obtained films from blends of two polysaccharides (glucomannan and sodium alginate) and a protein (collagen). The barrier and mechanical properties of whey-based protein films were improved by adding either sodium alginate or pectin (PARRIS et al., 1995) or methylcellulose (ERDOHAN; TURHAN, 2005). Gelatin-based films were improved by adding small amounts of polysaccharides, such as gellan and k-carrageenan (PRANOTO; LEE; PARK, 2007) or glucomannan (XIAO et al., 2001b). Pectin-based films were improved by adding small amounts of either fish skin gelatin or wheat gluten (LIU et al., 2007).

The aims of this study were to produce films from blends of methylcellulose, glucomannan, pectin and gelatin; to evaluate the effects of component and $\mathrm{pH}$ ratios in the resulting films; and to determine ratios and conditions that result in films with better mechanical properties and water vapor permeability.

\section{Materials and methods}

\subsection{Materials}

Methylcellulose, METHOCEL A4M, donated by Dow Brasil S.A. Company (São Paulo, Brazil); konjac flour KONJAC M202, whose main polysaccharide is glucomannan, donated by Kalys S.A. Company (Saint-Ismier, France); pectin with a high degree of esterification (DE about 75\%), PECTINA GENU ${ }^{\circ}$, donated by CP Kelco Brasil S.A. Co. (Limeira, Brazil); and bovine skin type B gelatin, donated by 'Indústria Gelita do Brasil Ltda.' (São Paulo, Brazil), potassium sorbate purchased from Plury Química Ltda. Company (Diadema, Brazil). Other reagents used in the experiments were of analytical grade.

\subsection{Film formation}

Films were produced by using the solvent-casting technique, without plasticizers and in two stages. First, polysaccharides-based films (methylcellulose, glucomannan and pectin) were produced in different proportions in order to find out the formulation that resulted in films with better performance. This formulation was used in the second stage of the study along with gelatin. In both stages, the formulation composition effect on film properties was evaluated. The effect of the $\mathrm{pH}$ was evaluated in the second stage of the study.

For polysaccharide-based films, methylcellulose (1\%), glucomannan (0.75\%) and pectin (1\%) aqueous solutions were prepared in the presence of potassium sorbate $\left(0.2 \mathrm{~g} .100 \mathrm{~g} \mathrm{~g}^{-1}\right.$ of polysaccharide). Potassium sorbate was used to prevent fungus growing during the drying stage of films. Methylcellulose was dispersed in a small amount ( $1 / 4$ of the total water) of hot water at $80{ }^{\circ} \mathrm{C}$ and then, cold water at $10{ }^{\circ} \mathrm{C}$ was added to complete the total water volume. The dispersion was kept under constant agitation until complete solubilization. Pectin and glucomannan were dispersed in distilled water (at room temperature, $25 \pm 1^{\circ} \mathrm{C}$ ) under constant agitation until complete solubilization. Yet, the glucomannan solution was centrifuged (Damon/IEC Division Spinner, model HN-S, Needham, USA) at $3000 \times \mathrm{g}$ for 40 minutes in order to remove insoluble solids that could damage the film appearance. To obtain films with a desired ratio for each polysaccharide, different volumes of the three solutions were blended for 1 hour. The $\mathrm{pH}$ of each polysaccharide solution was adjusted to 4 with $\mathrm{HCl}(0.05 \mathrm{~N})$ and $\mathrm{NaOH}(0.05 \mathrm{~N})$ and re-adjusted during the mixture, when necessary, in order to assess the antimicrobial effectiveness. The ratio, on dry mass basis, of those three polysaccharides (Table 1) was designed by Statistica 5.5 Software (Statsoft, Tulsa, USA) using the simplex-centroid experimental design.

For polysaccharides/gelatin-based films, Formulation 9 (Table 1) was used in combination with gelatin only. In order to do so, the solution containing polysaccharides was added to the aqueous gelatin solution (3\%) at ratios, on dry mass basis, of $10 / 0,9 / 1,7 / 3,5 / 5,3 / 7,1 / 9$, and $0 / 10$, respectively, and the set was blended at $100 \mathrm{rpm}$ for 30 minutes using a mechanical shaker (Ika Labortechnik, IKA RW20.n, Staufen, Germany) at room temperature. As the $\mathrm{pl}$ of type $\mathrm{B}$ gelatin varies from 4.8 to 5.2 (POPPE, 1997), the $\mathrm{pH}$ of the blends was adjusted to 4 , 5 , and 6 to evaluate the effect of gelatin repulsive and attractive 
forces on the film properties. The $\mathrm{pH}$ was adjusted with $\mathrm{HCl}$ $(0.05 \mathrm{~N})$ and $\mathrm{NaOH}(0.05 \mathrm{~N})$ in each biopolymer solution and re-adjusted during the mixture, when necessary.

Film-forming solutions containing polysaccharides and gelatin were spread onto polyester plates and they were dehydrated under natural conditions $\left(25 \pm 1{ }^{\circ} \mathrm{C}, 50 \pm 2 \%\right.$ relative humidity, RH) for 60 hours. The formed films were removed from the plates and kept at $25 \pm 1{ }^{\circ} \mathrm{C}$ in a desiccator containing saturated solution of $\mathrm{Mg}\left(\mathrm{NO}_{3}\right)_{2} \cdot 6 \mathrm{H}_{2} \mathrm{O}(50 \pm 2 \% \mathrm{RH})$ for 72 hours before film characterization.

\subsection{Film characterization}

\section{Humidity content}

The humidity content was determined gravimetrically and in triplicate in accordance with AOAC (ASSOCIATION..., 1997), using an oven with air circulation and renewal (Tecnal, model TE-394/2, São Paulo, Brazil) at $110^{\circ} \mathrm{C}$, until steady weight was accomplished.

\section{Film thickness}

Film thickness was measured by using a digital micrometer (Mituto, Tokyo, Japan) with $0-25 \mathrm{~mm}$ scale and $0.001 \mathrm{~mm}$ accuracy. The values showed represent the means of seven measurements randomly taken during each evaluated sample.

\section{Mechanical properties}

The mechanical properties were determined according to the ASTM D882-98 (AMERICAN..., 1998) method, using a texture analyzer (Stable Micro Systems, TA-XT2, Godalming, UK) and the Texture Expert V. 1.22 Software. Films were cut into $25 \mathrm{~mm}$ wide strips and at least $10 \mathrm{~cm}$ long. The grip separation and crosshead speed were $50 \mathrm{~mm}$ and $1 \mathrm{~mm} / \mathrm{s}$, respectively. Film thickness varied from 0.019 to $0.028 \mathrm{~mm}$. Mechanical determinations were made in triplicate.

\section{Water vapor permeability}

The WVP was determined gravimetrically according to the ASTM E96-95 (AMERICAN..., 1995) method. The films were fixed over acrylic cells (with a depth of $21 \mathrm{~mm}$ and an internal diameter of $44 \mathrm{~mm}$ ). The interior of the cell was filled with calcium chloride $(0 \% \mathrm{RH})$ in such a way that the distance between the chloride surface and the surface in the lower side of the film was about $10 \mathrm{~mm}$. Then, the cells were placed in desiccators containing saturated solution of $\mathrm{NaCl}(75.0 \pm 2 \%$ RH) and weighed on analytical scale (Ohaus, AS200, Florham Park, USA) with $0.0001 \mathrm{~g}$ accuracy at $0,8,24,32$ and 48 hours. Determinations were made in triplicate and the WVP was calculated through Equation (1).

$W V P=(w / t) \cdot(x / \Delta P \cdot A)$

where, $w / t(\mathrm{~g} / \mathrm{h})$ corresponds to the water mass absorbed by the system as to the time calculated by linear regression $\left(\mathrm{R}^{2}>0.99\right)$ from weight date obtained during 48 hours, $A$ $\left(\mathrm{m}^{2}\right)$ is the exposed film area, $x(\mathrm{~mm})$ is the film thickness $(0.019-0.028 \mathrm{~mm})$, and $\Delta P(\mathrm{kPa})$ is the partial pressure difference through the film calculated through Equation (2).

$\Delta P=S\left(R_{1}-R_{2}\right)$

$S$, is the saturated vapor pressure at $25^{\circ} \mathrm{C}(3166 \mathrm{kPa}), R_{1}$ and $\mathrm{R}_{2}$ are the relative humidity in the desiccator $(0.75)$ and in the interior of the cell $(0.0)$, respectively, expressed in fractions.

\subsection{Statistical analyses of results}

The experimental results were evaluated using the ANOVA test and Tukey's multiple test, making use of the statistic program 'Statistical Analysis Systems' (SAS, Version 8.0, Cary, USA). The statistical analyses were carried out within the $95 \%$ confidence interval.

\section{Results and discussion}

\subsection{Properties of polysaccharides-based films}

\section{Mechanical properties}

The tensile strength (TS) and elongation (Table 1) values are within values reported in the literature for films based on methylcellulose (8 - $71 \mathrm{MPa}$ and $6-14 \%$ ) (DONHOWE; FENNEMA, 1993; TURHAN; ŞAHBAZ, 2004), arabinoxylan

Table 1. The mean tensile strength (TS), elongation (E), humidity content (HC), water vapor permeability (WVP) values of films produced from blends containing different ratios of methylcellulose $(\mathrm{M})$, glucomannan $(\mathrm{G})$ and pectin $(\mathrm{P})$.

\begin{tabular}{|c|c|c|c|c|c|c|c|}
\hline \multirow[t]{2}{*}{ Formulation } & \multicolumn{3}{|c|}{ Polysaccharide ratio } & \multicolumn{4}{|c|}{ Films properties } \\
\hline & $\mathrm{M}$ & G & $\mathrm{P}$ & $\begin{array}{c}\mathrm{TS} \\
(\mathrm{MPa})\end{array}$ & $\begin{array}{c}\mathrm{E} \\
(\%)\end{array}$ & $\begin{array}{l}\mathrm{HC} \\
(\%)\end{array}$ & $\begin{array}{c}\text { WVP } \\
\left(\mathrm{g} . \mathrm{mm} / \mathrm{hour}^{2} \mathrm{~m}^{2} \mathrm{kPa}\right)\end{array}$ \\
\hline F1 & 1 & 0 & 0 & $38.6^{\mathrm{e}, \mathrm{f}}$ & $4.4^{\mathrm{b}, \mathrm{c}}$ & $2.9^{c}$ & $0.294^{c}$ \\
\hline $\mathrm{F} 2$ & 0 & 1 & 0 & $58.5^{c}$ & $5.6^{\mathrm{b}}$ & $6.5^{\mathrm{b}, \mathrm{c}}$ & $0.204^{\mathrm{g}}$ \\
\hline F3 & 0 & 0 & 1 & $51.1^{\mathrm{d}}$ & $2.6^{\mathrm{c}, \mathrm{d}}$ & $10.5^{\mathrm{a}}$ & $0.282^{\mathrm{c}, \mathrm{d}, \mathrm{e}}$ \\
\hline $\mathrm{F} 4$ & 0.5 & 0.5 & 0 & $41.2^{\mathrm{e}, \mathrm{f}}$ & $3.7^{\mathrm{b}, \mathrm{c}, \mathrm{d}}$ & $6.7^{\mathrm{b}}$ & $0.317^{\mathrm{b}}$ \\
\hline F5 & 0.5 & 0 & 0.5 & $42.7^{\mathrm{e}}$ & $3.5^{\mathrm{c}, \mathrm{d}}$ & $4.3^{\mathrm{c}, \mathrm{d}, \mathrm{e}}$ & $0.272^{\mathrm{d}, \mathrm{e}}$ \\
\hline F6 & 0 & 0.5 & 0.5 & $64.7^{\mathrm{b}}$ & $3.3^{\mathrm{cd} d}$ & $6.0^{\mathrm{b}, \mathrm{c}}$ & $0.266^{\mathrm{e}, \mathrm{f}}$ \\
\hline F7 & 0.33 & 0.33 & 0.33 & $47.1^{\mathrm{d}}$ & $3.0^{\mathrm{c}, \mathrm{d}}$ & $5.3^{\mathrm{b}, \mathrm{c}, \mathrm{d}}$ & $0.292^{\mathrm{c}, \mathrm{d}}$ \\
\hline F8 & 0.67 & 0.17 & 0.17 & $37.3^{\mathrm{f}}$ & $3.9^{\mathrm{b}, \mathrm{c}, \mathrm{d}}$ & $3.4^{\mathrm{d}, \mathrm{e}}$ & $0.345^{\mathrm{a}}$ \\
\hline F9 & 0.17 & 0.67 & 0.17 & $72.6^{a}$ & $9.9^{\mathrm{a}}$ & $8.6^{\mathrm{a}, \mathrm{b}}$ & $0.265^{\mathrm{e}, \mathrm{f}}$ \\
\hline F10 & 0.17 & 0.17 & 0.67 & $42.7^{e}$ & $2.3^{\mathrm{d}}$ & $10.3^{\mathrm{a}}$ & $0.249^{f}$ \\
\hline
\end{tabular}

a-f, different letters in the same column indicate that values are significantly different $(\mathrm{p}<0.05)$ 
(27 MPa and 7\%) (PÉROVAL et al., 2002), glucomannan (80 MPa and 33\%) and chitosan (66 MPa and 32\%) (YE et al., 2006) obtained without plasticizers. The differences would be due to physical and chemical characteristics of the used polysaccharides, film production conditions and different thickness obtained. For instance, Ye et al. (2006) worked with purified glucomannan, whereas the current study used glucomannan that still had some fat and protein traces, according to the product specifications. Turhan and Şahbaz (2004) worked with different methylcellulose concentrations and observed that the higher the concentration, the higher the TS values and the film elongation, referred to concentrations that led to good polysaccharide solubilization and good film-forming solution spreading on the plate. The same tendency was also observed by Maftoonazad, Ramaswamy and Marcotte (2007) for high methoxyl pectin-based films plasticized with sorbitol. In the present research, low polysaccharide concentrations $(0.75 \%$ and $1 \%)$ were used because higher concentrations made it difficult to blend and spread the film-forming solution onto the plate, mainly due to the high viscosity of glucomannan.

Films obtained from the binary blend of glucomannan/pectin (F6) and from the ternary blend having a high glucomannan ratio (F9) (Table 1), presented higher TS values than those observed for individual components, indicating synergic interactions between the polysaccharides in these blends. On the other hand, the other blends resulted in films with TS values either similar to or lower than the ones in films based on individual components, indicating that the polysaccharide ratio affected their interactions significantly. Hence, when the main film fraction was methylcellulose or pectin (Table 1), the TS was reduced. Meanwhile, when glucomannan was the main film fraction, the TS was significantly improved. The effect of the biopolymer ratio on the mechanical properties of blended films was also observed by Xiao et al. (2001a), Ye et al. (2006) and Li et al. (2006) for films with binary blends of sodium carboximethylcellulose/glucomannan and chitosan/glucomannan, in which a high glucomannan ratio in the formulation resulted in films with high TS and elongation values.

In films obtained with binary blends containing methylcellulose, there was no synergic interaction between the components that resulted in TS improvement as observed in the pectin/glucomannan binary blend. Nevertheless, in films obtained with ternary blends containing low methylcellulose ratio, significant improvements in the mechanical properties were observed (F9). The use of three polysaccharides altogether, instead of two, in film production was also favorable for Tong, Xiao and Lim (2008). According to these authors, adding concentrations higher than $50 \%$ of sodium alginate or carboximethylcellulose (CMC) to pullulan significantly jeopardized the mechanical performance of the resulting binary films. However, the combined addition of alginate and CMC to pullulan, in order to form a three-component film, allowed the incorporation of a greater ratio of alginate and CMC with smaller loss of mechanical performance.

The film obtained with a high glucomannan ratio (F9, Table 1) that showed the highest TS also had the highest elongation (9.9\%) when compared to other formulations $(2.3 \%$
- 5.6\%). The high elongation value observed for this film (F9, Table 1) may be attributed to the highly ramified nature of glucomannan (MAEDA et al., 1999) that can lead to a looser molecular network and molecular movement, which is relatively free, then obtaining more flexible films.

When compared to values reported for synthetic films (PÉROVAL et al., 2002), TS values obtained were higher than those observed for low-density polyethylene - LDP (13 - $28 \mathrm{MPa}$ ) and lower than those for cellophane (114 MPa). Nevertheless, these synthetic films showed higher elongation values $(\mathrm{LDP}=100 \%$, cellophane $=20 \%)$ than the results obtained in the current study.

As films were made without plasticizers, the influence of humidity content on the elongation results was evaluated, because water molecules can also act as plasticizing agents, increasing mobility between polymer chains. Low, intermediate and high humidity contents were observed in films made from methylcellulose, glucomannan and pectin, respectively, and the ternary blends with higher ratio of these polysaccharides presented the same tendency (Table 1). For films that showed high $(10.5 \%$ and $10.3 \%)$ and low $(2.9 \%$ and $3.4 \%)$ humidity contents, there was no significant difference between elongation values $(2.6 \%-4.4 \%)$. On the other hand, films made from glucomannan or from the blend with higher ratio of this biopolymer (F9) presented intermediate humidity content $(6.5 \%$ e $8.6 \%$ ) and higher elongation values (5.6\% and 9.9\%). Thus, there is no direct relationship between humidity content and elongation values.

\section{Water vapor permeability}

The WVP values obtained (Table 1) were similar to those obtained for films without plasticizers made from methylcellulose (0.312 g.mm/ $\left.\mathrm{m}^{2} . \mathrm{h} . \mathrm{kPa}\right)$ (DONHOWE; FENNEMA, 1993), arabinoxylan (0.635 g.mm/ $\left.\mathrm{m}^{2} . \mathrm{hkPa}\right)$ (PÉROVAL et al., 2002) and hydropropylmethylcellulose (0.358 g.mm $/ \mathrm{m}^{2} \mathrm{~h} . \mathrm{kPa}$ ) (PHAN THE et al., 2002). The binary and ternary polysaccharide blends did not result in significant improvement in WVP when compared to individual components. There was a significant increase in WVP in the films made from the methylcellulose/glucomannan binary blend or from the ternary blend containing high methylcellulose ratio (Table 1). Films made from other blends had WVP values with no significant difference when compared to the WVP values of methylcellulose and pectin films (Table 1). The lowest WVP value was observed in glucomannan-based films. Li et al. (2006) did not observe improvements in WVP either, due to the blend of different glucomannan and chitosan ratios; and other authors (XIAO et al., 2001a; YE et al., 2006; LI et al., 2006) have reported the results only as to the film mechanical properties.

\subsection{Polysaccharide and gelatin films}

Properties of polysaccharide-gelatin-based films with different ratios and $\mathrm{pH}$ values are presented in Figures 1, 2 and 3. For every formulation, the polysaccharides included methylcellulose, glucomannan and pectin at ratio $1: 4: 1$, respectively (F9 in Table 1). This ratio resulted in films with 
improved mechanical properties compared to those shown in Table 1.

\section{Mechanical Properties}

The polysaccharide-based films presented TS values (69$76 \mathrm{MPa}$ ) higher than the gelatin-based films (59-63 MPa) and the mixture polysaccharide-gelatin-based films $(42-72 \mathrm{MPa})$ produced at different $\mathrm{pHs}$ (Figure 1). The lowest values were observed in combinations containing the same gelatin and polysaccharide amounts, and the TS was reduced 37, 20 and $12 \%$ for films produced at pHs 4,5 and 6 , respectively, when compared to polysaccharides-based films. However, the combination between gelatin and small amounts of polysaccharides (gelatin/polysaccharides, 90/10) resulted in films with TS values higher than those in pure gelatin films, showing increase between 14 and $22 \%$ in TS to films produced at $\mathrm{pH} 4$ and 6 , respectively. Furthermore, tensile strength values of blended films and pure gelatin films, at $\mathrm{pH} 5$, did not show significant differences $(\mathrm{p}>0.05)$.

The influence of the component ratios on the mechanical properties of films made from polysaccharide and protein blends was also observed by Xiao et al. (2001b) and Zhong and Xia (2008). In films produced with different gelatin and glucomannan ratios, high TS values were observed for films containing high gelatin ratios (XIAO et al., 2001b). Likewise, in chitosan, starch and gelatin films, high TS values were observed for those films produced with low gelatin concentration and high cassava starch concentration (ZHONG; XIA, 2008). According to Zhong and Xia (2008), the significant increase in TS is attributed to the presence of intermolecular interactions between biopolymers; observations which were confirmed by the authors through infrared and X-ray analyses.

The elongation values decreased due to gelatin addition in the blends (Figure 2). A similar tendency was observed by Xiao et al. (2001b) for glucomannan/gelatin films, as elongation decreased as gelatin increased in the blends. Only a few differences were observed between films produced at different $\mathrm{pHs}$ in the same blend. Nevertheless, the film produced from the polysaccharides at $\mathrm{pH} 5$ presented higher elongation values than

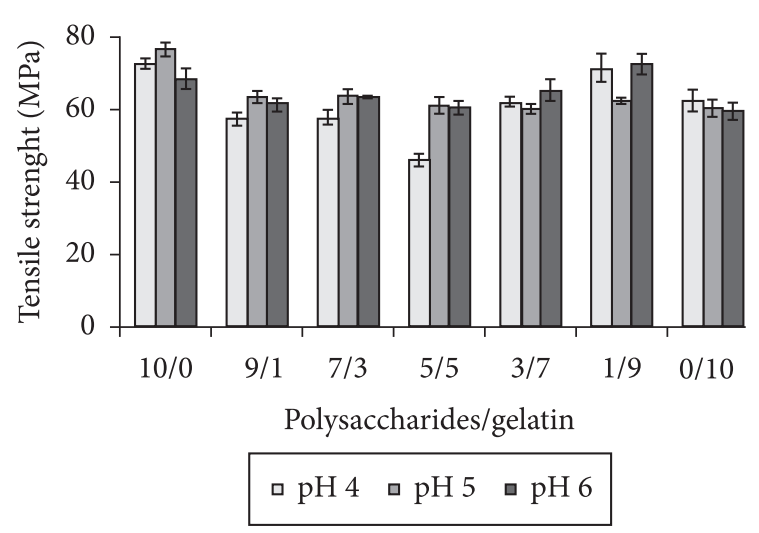

Figure 1. Tensile strength of the polysaccharides and gelatin films at different $\mathrm{pHs}$ and components ratio. The results are expressed as means of each treatment and the error bars ( I ) represent the standard deviation. other formulations. The high elongation value can be attributed to the highly ramified nature of glucomannan, which is found at a higher ratio $(66.7 \%)$ in polysaccharide blends.

The TS and elongation values obtained (46.1 - 76.5 MPa and $2.9 \%-13.6 \%$ ) are within the range of values reported by the literature for films produced with sodium collagen-glucomannan-alginate blends $(28.5$ - $104 \mathrm{MPa}$ and $8.2 \%-14.8 \%$ ) (WANG et al., 2007), gelatin-pectin (17 - 71.8 MPa and $2.5 \%-6.4 \%$ ) (LIU et al., 2007), gelatin- gellan gum or carrageenans (101.2 - 109.8 MPa and 5.0\% - 6.8\%) (PRANOTO; LEE; PARK, 2007), gelatin-glucomannan (10 - $38 \mathrm{MPa}$ and $2.5 \%-7.7 \%$ ) (XIAO et al., 2001b), and gelatin modified potato starch (86.7 - 95.3 MPa and 2.4\% - 2.7\%) (ARVANITOYANNIS; NAKAYAMA; AIBA, 1998).

\section{Water vapor permeability}

WVP values varied as to $\mathrm{pH}$ and polysaccharide and gelatin ratios in the blend (Figure 3). Films produced from the polysaccharides at $\mathrm{pH} 5$ had significantly lower WVP values than those produced at pHs 4 and 6 (Figure 3), indicating favorable interactions between methylcellulose, glucomannan

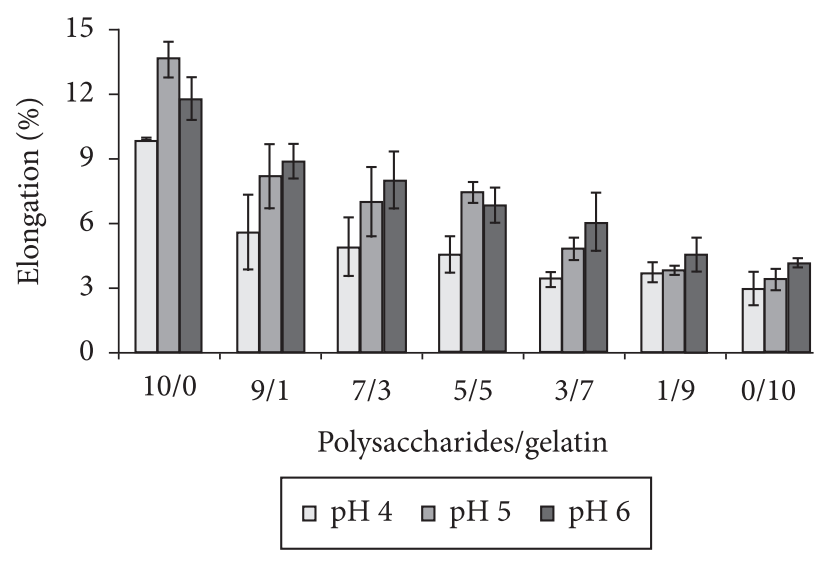

Figure 2. Elongation of the polysaccharides and gelatin films at different $\mathrm{pHs}$ and components ratio. The results are expressed as means of each treatment and the error bars represent ( I ) the standard deviation.

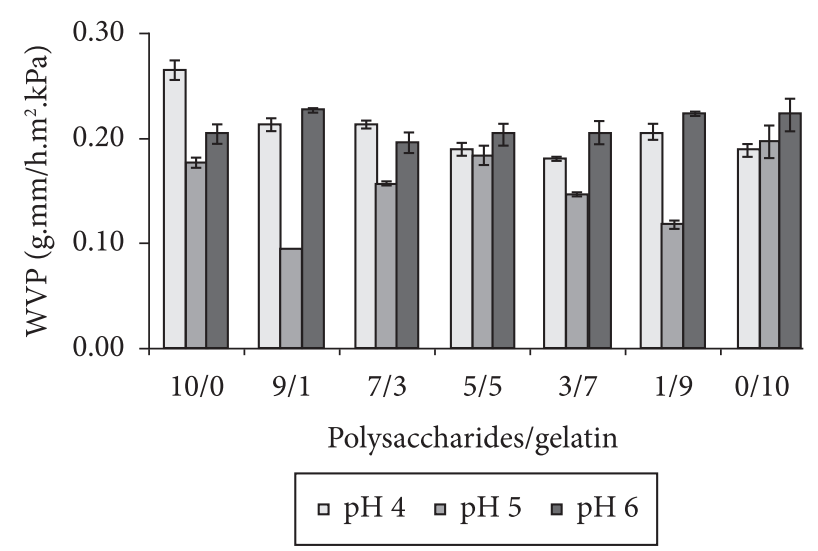

Figure 3. Water vapor permeability (WVP) of the polysaccharides and gelatin films at different $\mathrm{pHs}$ and components ratio. The results are expressed as means of each treatment and the error bars represent ( I ) the standard deviation. 
and pectin at $\mathrm{pH}$ 5. The smallest WVP values were observed in films produced with polysaccharides/gelatin ratios of $9 / 1$ and $1 / 9$ at $\mathrm{pH} 5$, showing a reduction of approximately $43 \%$ when compared to polysaccharides only or gelatin only films. The results suggested that there were improvements in the barrier properties to water vapor when gelatin or polysaccharides were found in smaller amounts ( $11 \%$ of protein or polysaccharide mass) in blends. These observations are in accordance with the literature, in which better mechanical properties and water vapor permeability were observed for fish gelatin films and calcium caseinate/ whey protein isolate films, due to addition of gellan gum, k-carrageenan, potato starch or sodium alginate in small amounts ( $2 \%-5 \%$ of protein mass) (PRANOTO; LEE; PARK, 2007; CIEŚLA; SALMIERI; LACROIX, 2006).

Considering that the type $\mathrm{B}$ gelatin isoelectric point varies from 4.8 to 5.2 (POPPE, 1997), below $\mathrm{pH} 4.8$ gelatin is positively charged, whereas pectin, whose pKa varies from 3 to 3.3, (VORAGEN et al., 1995) is negatively charged. This situation could favor a better electrostatic association between these components in the blend at $\mathrm{pH} 4$. Since the WVP value of the films was lower at $\mathrm{pH} 5$, the electrostatic interaction may not have been determinant in decreasing the matrix porosity and consequently, increasing the barrier to water vapor diffusion through films. The $\mathrm{pH}$ effect on the WVP of films containing glucomannan, chitosan and soy protein isolate (SPI) was also evaluated by Jia, Fang and Yao (2009). In that study, the WVP of the films was reduced approximately $40 \%$ when the $\mathrm{pH}$ varied from 4 to 5 . According to the authors, with an increase in $\mathrm{pH}$ values, the present forms and charge distribution of SPI and chitosan in the system will change, and more free amino groups will be present, forming more hydrogen bonds. In addition, possibly decreased solubility of SPI and chitosan at pH 5 may cause some of them sediment in the network, thus enhancing the compactness of the film. Therefore, the film showed the lowest WVP at this pH (JIA; FANG; YAO, 2009).

The lowest WVP value for the polysaccharides/gelatin blend at the ratio $9 / 1\left(0.09\right.$ g.mm $\left./ \mathrm{h} . \mathrm{m}^{2} . \mathrm{kPa}\right)$ is within the range of values reported in the literature for sodium caseinate, whey protein isolate and sodium alginate blended films (CIEŚLA; SALMIERI; LACROIX, 2006), as well as to methylcellulose and whey protein isolate - blended films (ERDOHAN; TURHAN, 2005). When compared to synthetic materials, the value is lower than the values observed in cellophane films (0.248 g.mm $\left./ \mathrm{h} . \mathrm{m}^{2} . \mathrm{kPa}\right)$ (PÉROVAL et al., 2002), and similar to the permeability value observed in PVC films $(0.02 \mathrm{~g} . \mathrm{mm} / \mathrm{h}$. $\mathrm{m}^{2} . \mathrm{kPa}$ ). However, it is higher than that observed in low density polyethylene (0.0072 g.mm/h.m².kPa) (PÉROVAL et al., 2002).

\section{Conclusions}

Both components ratio and different $\mathrm{pH}$ values of filmforming solution significantly affected not only the mechanical but also the WVP properties of films based on methylcellulose, glucomannan, pectin and gelatin. Considering films produced from polysaccharides, the ternary blend containing high glucomannan ratio (66.7\%) resulted in films with high tensile strength and elongation values when compared to other films. Nevertheless, the binary and ternary polysaccharides blends did not result in significant improvements in the WVP of the films when compared to individual components. The polysaccharide-based films presented the best mechanical properties when compared to gelatin-based ones or those produced with different polysaccharides/gelatin blends. The TS values of gelatin-based films improved due to small amounts of polysaccharides ( $11 \%$ of protein mass) added to the formulation. The $\mathrm{pH}$ allowed changes in interactions between polysaccharides and gelatin, resulting in films with water vapor barrier properties that were more effective at $\mathrm{pH} 5$ and with polysaccharides/gelatin ratios of $9 / 1$ and $1 / 9$. The use of blends containing methylcellulose, glucomannan and pectin in films was effective in improving mechanical properties, whereas adding gelatin to the polysaccharide blend and adjusting the $\mathrm{pH}$ were effective in improving water vapor barriers properties.

\section{Acknowledgements}

The authors are grateful to PEC-PG and CNPQ for the scholarship provided to the first author and for their research support, and to Kalys, Dow, CP Kelco and Gelita companies and industries as well, for the donations of the materials used in this study.

\section{References}

AMERICAN SOCIETY FOR TESTING AND MATERIALS - ASTM. Standard test method for water vapor transmission of materials E96-95. In: STORER, R. A. (Ed.). Annuals Book of ASTM Standards. Philadelphia: American Society for Testing and Materials, 1995. p. 697-704.

AMERICAN SOCIETY FOR TESTING AND MATERIALS - ASTM. Standard test method for tensile properties of thin plastic sheeting D882-98. In: STORER, R. A. (Ed.). Annuals Book of ASTM Standards. Philadelphia: ASTM, 1998. p. 163-171.

ARVANITOYANNIS, I.; NAKAYAMA, A.; AIBA, S-I. Edible films made from hydroxypropyl starch and gelatin and plasticized by polyols and water. Carbohydrate Polymers, v. 36, n. 2, p. 105-119, 1998. http://dx.doi.org/10.1016/S0144-8617(98)00017-4

ASSOCIATION OF OFFICIAL ANALYTICAL CHEMIST - AOAC. Association of Official Analytical Chemist Official Methods of Analysis. 16th ed. Washington: AOAC, 1997.

BERTAN, L. C. et al. Effect of fatty acids and "Brazilian elemi" on composite films based on gelatin. Food Hydrocolloids, v. 19, n. 1, p. 73-82, 2005. http://dx.doi.org/10.1016/j.foodhyd.2004.04.017

CAO, N.; YANG, X.; FU, Y. Effects of various plasticizers on mechanical and water vapor barrier properties of gelatin films. Food Hydrocolloids, v. 23, n. 3, p. 729-735, 2009. http://dx.doi. org/10.1016/j.foodhyd.2008.07.017

CARPITA, N.; McCANN, M. The Cell Wall. In: BUCHANAN, B. B.; GRUÍSSEM, W. W.; JONES, R. L. (Eds.). Biochemistry and Molecular Biology of Plants. Rockville: American Society of Plant Physiologists, 2000. cap. 2, p. 52-108.

CARVALHO, R. A.; GROSSO, C. R. F. Characterization of gelatin-based films modified with transglutaminase, glyoxal and formaldehyde. Food Hydrocolloids, v.18, n. 5, p. 717-726, 2004. http://dx.doi. org/10.1016/j.foodhyd.2003.10.005

CHAMBI, H.; GROSSO, C. Edible films produced with gelatin and casein cross-linked with transglutaminase. Food Research International, v. 39, n. 4, p. 458-466, 2006. 
CHANLIAUD, E. et al. Mechanical properties of primary plant cell wall analogues. Planta, v. 215, n. 6, p. 989-996, 2002. http://dx.doi. org/10.1007/s00425-002-0783-8

CHEN, H. Functional properties and applications of edible films made of milk proteins. Journal of Dairy Science, v. 78, n. 11, p. 25632583, 1995. http://dx.doi.org/10.3168/jds.S0022-0302(95)76885-0

CHENG, L. H. et al. Modification of microstructural and physical properties of konjac glucomannan-based films by alkali and sodium carboxymethylcellulose. Food Research International, n. 9, v. 35, p. 829-836, 2002. http://dx.doi.org/10.1016/S0963-9969(02)00086-8

CIEŚLA, K.; SALMIERI, S.; LACROIX, M. $\gamma$-Irradiation influence on the structure and properties of calcium caseinate-whey protein isolate based films. Part 2. Influence of polysaccharide addition and radiation treatment on the structure and functional properties of the films. Journal of Agricultural and Food Chemistry, v. 54, n. 23, p. 8899-8908, 2006. http://dx.doi.org/10.1021/jf060981k

DEBEAUFORT, F.; VOILLEY, A. Methylcellulose-based edible films and coatings: 2. Mechanical and thermal properties as a function of plasticizer content. Journal of Agricultural and Food Chemistry, v. 45, n. 3, p. 685-689, 1997. http://dx.doi.org/10.1021/jf9606621

DJAGNY, K. B.; WANG, Z.; XU, S. Gelatin: a valuable protein for food and pharmaceutical industries: Review. Critical Reviews in Food Science and Nutrition, v. 41, n. 6, p. 481-492, 2001. http://dx.doi. org/10.1080/20014091091904

DONHOWE, I. G.; FENNEMA, O. The effect of solution composition and drying temperature on crystallinity, permeability and mechanical properties of methylcellulose films. Journal of Food Processing and Preservation, v. 17, n. 4, p. 231-246, 1993. http:// dx.doi.org/10.1111/j.1745-4549.1993.tb00728.x

ERDOHAN, Z. Ö.; TURHAN, K. N. Barrier and mechanical properties of methylcellulose-whey protein films. Packaging Technology and Science, v. 18, n. 6, p. 295-302, 2005. http://dx.doi.org/10.1002/ pts.700

GENNADIOS, A. et al. Edible coating and films based on proteins. In: KROCHTA, J. M.; BALDWIN, E. A.; NISPEROS-CARRIEDO, M. O. (Eds.). Edible Coatings and Films to Improve Food Quality. Lancaster: Technomic Publishing Company, 1994. cap. 9, p. 210-278.

HERNÁNDEZ-MUÑOZ, P.; VILLALOBOS, R.; CHIRALT, A. Effect of cross-linking using aldehydes on properties of glutenin-rich films. Food Hydrocolloids, v. 18, n. 3, p. 403-411, 2004. http://dx.doi. org/10.1016/S0268-005X(03)00128-0

JIA, D.; FANG, Y.; YAO, K. Water vapor barrier and mechanical properties of konjac glucomannan-chitosan-soy protein isolate edible films. Food And Bioproducts Processing, v. 87, n. 1, p. 7-10, 2009. http://dx.doi.org/10.1016/j.fbp.2008.06.002

JUNQUEIRA, L. C. U. Biología Celular e Molecular. Río de Janeiro: Guanabara Koogan, 1997. 299 p.

KERSTIENS, G. Signalling across the divide: a wider perspective of cuticular structure-function relationships. Trends in Plant Science, v. 1, n. 4, p. 125-129, 1996. http://dx.doi.org/10.1016/ S1360-1385(96)90007-2

KOELSCH, C. Edible water vapor barriers: properties and promise. Trends in Food Science and Technology, v. 5, n. 3, p. 76-81, 1994. http://dx.doi.org/10.1016/0924-2244(94)90241-0

KOHYAMA, K. et al. Dielectric, viscoelastic and broad-line NMR study of konjac glucomannan films. Carbohydrate Polymers, v. 17, n. 1, p. 59-63, 1992. http://dx.doi.org/10.1016/0144-8617(92)90023-J

KROCHTA, J. M.; DE MULDER-JOHNSTON, C. Edible and biodegradable polymer films: challenges and opportunities. Food Technology, v. 51, n. 2, p. 61-64, 1997.
LI, B. et al. Preparation and performance evaluation of glucomannanchitosan-nisin ternary antimicrobial blend film. Carbohydrate Polymers, v. 65, n. 4, p. 488-494, 2006. http://dx.doi.org/10.1016/j. carbpol.2006.02.006

LIU, L. et al. Composite films from pectin and fish skin gelatin or soybean flour protein. Journal of Agricultural and Food Chemistry, v. 55, n. 6, p. 2349-2355, 2007. http://dx.doi. org/10.1021/jf062612u

MAEDA, H. et al. Biodegradable Vegetable Film. Fuji Oil Co. Ltd., 1999. Patent Number US6004616.

MAFTOONAZAD, N.; RAMASWAMY, H. S.; MARCOTTE, M. Evaluation of factors affecting barrier, mechanical and optical properties of pectin-based films using response surface methodology. Journal of Food Process Engineering, v. 30, n. 5, p. 539-563, 2007. http://dx.doi.org/10.1111/j.1745-4530.2007.00123.x

MAY, C. D. Pectins. In: IMESON, A. (Ed.). Thickening and Gelling Agents for Food. London: Blackie Academic \& Professional, 1997. cap. 11, p. 230-261.

PARRIS, N. et al. Composition factors affecting the water vapor permeability and tensile properties of hydrophilic films. Journal of Agricultural and Food Chemistry, v. 43, n. 6, p. 1432-1435, 1995. http://dx.doi.org/10.1021/jf00054a004

PÉROVAL, C. et al. Edible Arabinoxylan-Based Films. Effects of lipids type on water vapor permeability, film structure, and other physical characteristics. Journal of Agricultural and Food Chemistry, v. 50, n. 14, p. 3977-3983, 2002.

PHAN THE, D. et al. Arabinoxylan-Lipids-Based edible films and coatings. 2. Influence of sucroester nature on the emulsion structure and film properties. Journal of Agricultural and Food Chemistry, v. 50, n. 2, p. 266-272, 2002.

PHAN THE, D. et al. Biopolymer interactions affect the functional properties of edible films based on agar, cassava starch and arabinoxylan blends. Journal of Food Engineering, v. 90, n. 4, p. 548-558, 2009.

POPPE, J. Gelatin. In: IMESON, A. (Ed.). Thickening and Gelling agents for Food. 2th ed. London: Blackie Academic and Professional, 1997. cap. 7, p. 144-179.

PRANOTO, Y.; LEE, C. M.; PARK, H. J. Characterizations of fish gelatin films added with gellan and k-carrageenan. Food Science and Technology, v. 40, n. 5, p. 766-774, 2007.

TAIZ, L.; ZEIGER, E. Plant Physiology. Sunderland: Sinawer Associates, Inc., 2002. 690 p.

TANADA-PALMU, P. S.; GROSSO, C. R. F. Wheat gluten composite and bilayer edible films: Effect of lipid addition. Research Advances in Agricultural and Food Chemistry, v. 3, p. 53-60, 2002.

TONG, Q.; XIAO, Q.; LIM, L. Preparation and properties of pullulan-alginate-carboxymethylcellulose blend films. Food Research International, v. 41, n. 10, p. 1007-1014, 2008. http:// dx.doi.org/10.1016/j.foodres.2008.08.005

TURHAN, K. N.; ŞAHBAZ, F. Water vapor permeability, tensile properties and solubility of methylcellulose-based edible films. Journal of Food Engineering, v. 61, n. 3, p. 459-466, 2004.

VORAGEN, A. G. J. et al. Pectins. In: STEPHEN, A. M. (Ed.). Food Polysaccharides and their Applications. New York: Marcel Dekker Inc., 1995. cap. 10, p. 287-339.

WANG, B. et al. Structure and properties of collagen-konjac glucomannan-sodium alginate blend films. Journal of Applied Polymer Science, v. 106, n. 1, p. 327-332, 2007. http://dx.doi. org/10.1002/app.26670 
XIAO, C. et al. Preparation and characterization of konjac glucomannan and sodium carboxymethylcellulose blend films. Journal of Applied Polymer Science, v. 80, n. 1, p. 26-31, 2001a.

$\mathrm{XIAO}$, C. et al. Characterization of konjac glucomannan-gelatin blend films. Journal of Applied Polymer Science, v. 79, n. 9, p. 1596-1602, 2001b. http://dx.doi.org/10.1002/10974628(20010404)80:1\%3C26::AID-APP1070\%3E3.0.CO;2-B

YE, X. et al. Condensed state structure and biocompatibility of the konjac glucomannan/chitosan blend films. Carbohydrate Polymers, v. 64, n. 4, p. 532-538, 2006. http://dx.doi.org/10.1016/j. carbpol.2005.11.005
YOO, M-H.; LEE, H-G.; LIM, S-T. Physical properties of the films prepared with glucomannan extracted from Amorphophallus konjac. Korean Journal of Food Science and Technology, v. 29, n. 2, p. 255-260, 1997.

ZECHER, D.; GERRISH, T. Cellulose derivatives. In: IMESON, A. (Ed.). Thickening and Gelling Agents for Food. London: Blackie Academic \& Professional, 1997. cap. 4, p. 60-85.

ZHONG, Q-P.; XIA, W-S. Physicochemical properties of edible and preservative films from chitosan/cassava starch/gelatin blend plasticized with glycerol. Food Technology and Biotechnology, v. 46, p. $262-269,2008$. 